$ノ-卜$

\title{
微量エッチング粗化後の銅と樹脂材料の密着性能
}

\author{
文 蔵 隆 志 ${ }^{\text {a,* }}$ \\ a(株) JCU 総合研究所 ( ⿳ 215-0033 神奈川県川崎市麻生区栗木 2-4-3)

\section{Adhesion Performance of the Resin Material to Copper That Has Been Roughened by Small Amount Etching}

Takashi FUMIKURA ${ }^{\text {a,* }}$

${ }^{\text {a }}$ R\&D Center, JCU CORPORATION(2-4-3, Kurigi, Asao-ku, Kawasaki-shi, Kanagawa 215-0033)

\begin{abstract}
Currently, the main method used to maintain adhesion between $\mathrm{Cu}$ and insulating material (resin) on PWB is forming roughness on a $\mathrm{Cu}$ surface using chemical etching and acquisition of adhesion by the anchor effect. We conducted an examination with the intention of using the technology to maintain sufficient adhesion with the etching solution that forms fine roughness by approximately $1 / 10$ of the etching amount of a conventional micrometer-order etching solution.
\end{abstract}

Keywords : Etching, Adhesion, Surface Treatment, Printed-Circuit Board

\section{1. 目的}

現在，プリント配線板における銅－絶縁材(樹脂)間の密着 性を確保する手段として, 銅表面を化学エッチングで粗面化 させて凹凸を形成し，そのアンカー(投錨)効果によって密着 を得る方法が主流となっている。

例えば，ビルドアップフィルムやプリプレグの積層前のプ ロセスに関しては, 上記エッチング粗化法を用いて $\mu \mathrm{m}$ オー ダーの凹凸を形成させて, 表面積 = 密着面積の増加とアン カー効果との相乗効果によって銅配線と樹脂間の密着を確保 している。

しかしながら, 近年のスマートフォンに代表される電子機 器の高密度化・高性能化要求により, 内蔵されるプリント配 線においては微細化が進んでおり， $\mu \mathrm{m}$ オーダーの粗化では 配線幅減少による導体体積減少や配線剥離, 回路表面上の表 皮抵抗に伴う伝送損失等の問題が懸念されている ${ }^{1)}$ 。

その他, 微細配線形成技術に代表されるセミアディティブ プロセスにおいては, 前記表皮抵抗低減対応として, ビルド アップフィルムの低粗度化が進んでおり，これに伴いその樹 脂層に形成される無電解銅めっき(シード層) も平滑性を有し てアンカー効果が得られないため, パターンレジスト(ドラ イフィルム)に対して密着性の確保が困難になってきている。 この問題に関して, 一般のエッチング粗化液を用いてドライ フィルムレジストとの密着性を得ようとしても, シード層の 厚さは $1 \mu \mathrm{m}$ 前後の非常に薄い銅厚のため, 粗化が形成され る前にシード層が溶解除去(エッチングアウト)してしまうの で，現状では銅表面をエッチングしない酸洗浄等の表面ク

\footnotetext{
*E-mail : fumikura.takashi@jcu-i.com
}

リーニングに留まっている。

このような状況において, エッチング法を用いない多種多 様な粗化レス密着処理 (接着層形成)が試みられているが，接 着層の除去性や後工程との相性および性能管理等の懸念が残 されている。また一方では，ある程度の粗化による凹凸=ア ンカー効果を保持させて銅－樹脂間の密着信頼性や耐薬品性 を確保させる技術も必須であるとの意見もある。

様々な要求の中, 我々は「低エッチング量」かつ「微細粗 化形状」を得られるエッチング液の開発を行った。

これまで一般的に使用されている $\mu \mathrm{m}$ オーダーのエッチン グ粗化液の開発では無く, さらに $1 / 10$ 程度の低エッチング 量 $(\mathrm{nm} /$ ナノオーダー)で, 微細な凹凸を形成させるエッチ ング液 (以下, 微量エッチング粗化液)として, 銅一絶縁材料 (樹脂)間の密着性を確保できる技術を目標に実験を行った。

以降に，我々の開発した「微量エッチング粗化液」の実験 結果を記す。

\section{2. 方 法}

2. 1 銅表面の微量エッチング粗化

粗化手法はウェットエッチング処理であり, 銅板を粗化 エッチング液に浸漬, 摇動し, 重量法によって算出したエッ チング量を元に所定量エッチングを施している。

図 1 に微量エッチング粗化液を用いた粗化処理前後の電解 銅めっき品 $(\mathrm{JCU}$ 社 : キューブライトVF II ) および, デスミ ア処理を施したビルドアップフィルム (味の素ファインテク ノ社：ABF-GX92)上の無電解銅めっき品 (JCU：FEED プロ セス)の SEM 像(倍率：10,000 倍) および，表面の算術平均 粗さ「Ra」について示す。また,一般的に使用されているエッ チング粗化液を用いた試料についても比較として示す。 

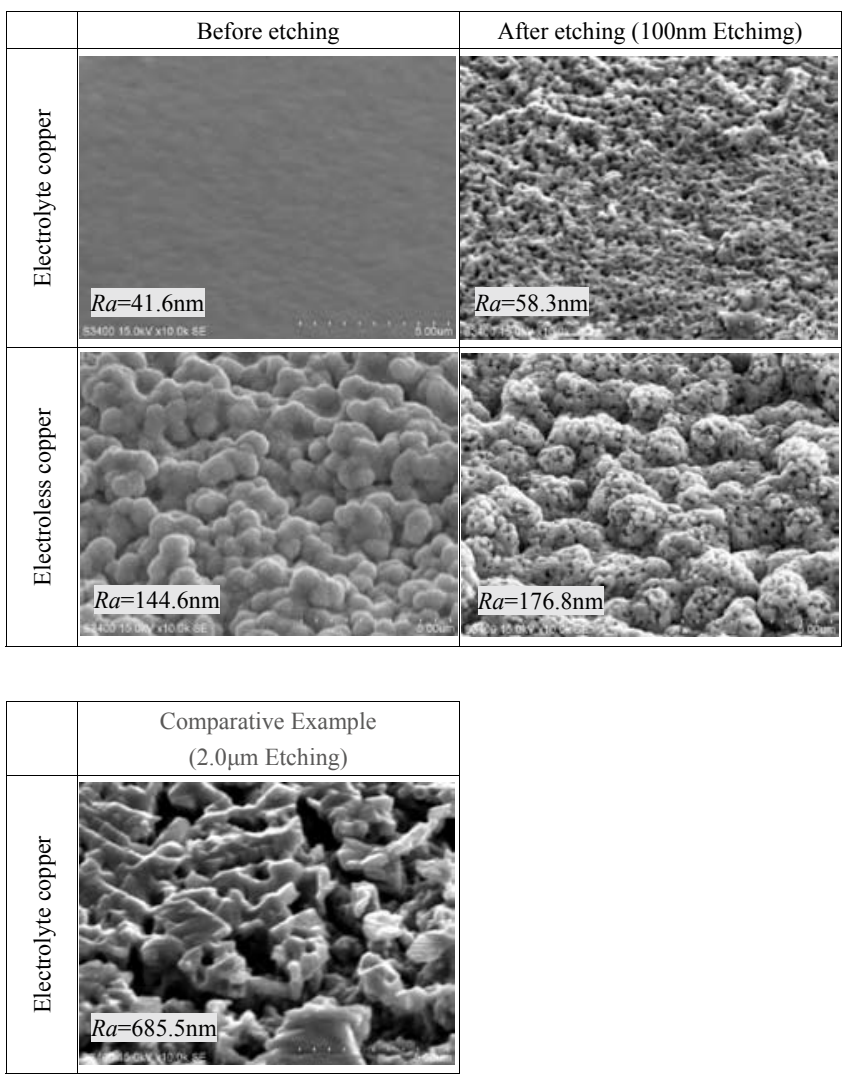

Fig. 1 SEM image of Copper surface

微量エッチング粗化後の銅表面形状は, 電解銅めっき品, 無電解銅めっき品共に微細な凹凸を形成しており，エッチン グ量も重量法換算值として $100 \mathrm{~nm}$ 程であるため, 処理前と ほぼ変わらない $R a$ 值であり低い值となっている。

この微細な凹凸のアンカー効果力を確認するために, 各種 絶縁材料を張り合わせて, 密着性を確認した。

\section{2 電解銅めっき品とビルドアップフィルムの密着性 評価}

電解銅めっき品 (JCU：キューブライトVF II,$t=35 \mu \mathrm{m}$ ) に対し, 微量エッチング粗化液を用いてエッチング量 $50 \mathrm{~nm}$, $100 \mathrm{~nm}$ エッチング(エッチング前後の重量法換算值)にて粗 化形成させた後, ビルドアップフィルム (味の素ファインテ クノ社：ABF-GX13, ABF-GX92)をラミネートして, ピール 強度測定を行った。

\section{3 電解銅めっき品とソルダーレジストの密着性評価}

電解銅めっき品 (JCU：キューブライト VF II ) 表面に対し 微量エッチング粗化液を用いてエッチング量 $50 \mathrm{~nm}, 100 \mathrm{~nm}$ エッチングにて粗化形成させた後, ソルダーレジスト (太陽 インキ社：PSR-4000)を $\phi 50$ の円柱ドットを 1076 個形成して, 現像後のドット残存数を確認した。また同サンプルに無電解 ニッケルめっき(JCU：SKYLITE プロセス)を施し, 同様に ドット残存数の確認を行った。

\section{4 無電解銅めっき品とドライフィルムレジストの密 着性評価}

デスミア処理を施したビルドアップフィルム(味の素ファ インテクノ社：ABF-GXT31) 上に無電解銅めっきを形成し, その表面に対して微量エッチング粗化にて $50 \mathrm{~nm}, 100 \mathrm{~nm}$

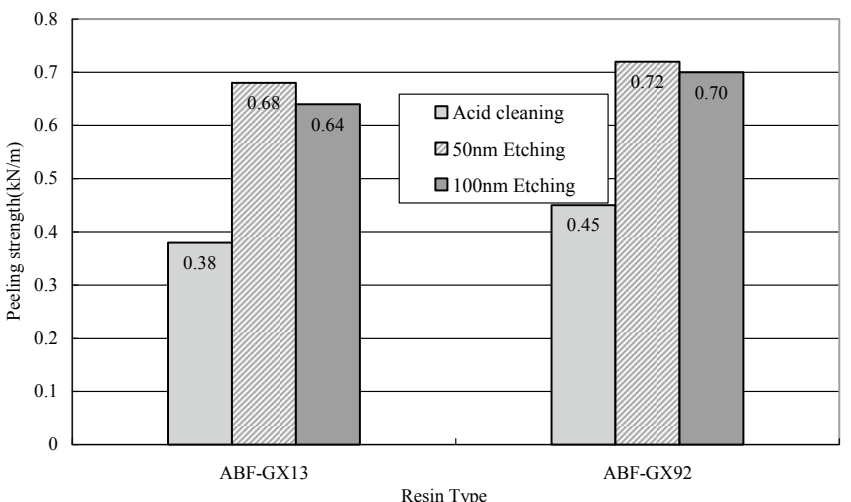

Fig. 2 Peeling test

エッチングして粗化を形成させた後, ドライフィルムレジス 卜 (旭化成：UFG-258)をラミネート後, ドライフィルムのレ ジスト幅 $3 \sim 10 \mu \mathrm{m}$ になるように露光・現像を行い, 残存 するドライフィルムレジストの最小幅を確認した。残存する ドライフィルムレジストの幅が狭いほど, 密着性に優れてい る。さらに，その後に電解銅めっきを施し，めっき後のドラ イフィルムレジストの残存最小幅の確認も同様に行った。

\section{3. 結 果}

\section{1 電解銅めっき品とビルドアップフィルムの密着性}

図 2 にピール強度 $\left(90^{\circ}\right.$ 剥離 $)$ 測定結果を示す。

一般的な粗化液は $1 \sim 2 \mu \mathrm{m}$ エッチングして，ピール強度 は $0.6 \sim 1.0 \mathrm{kN} / \mathrm{m}$ 程度であり, $0.6 \mathrm{kN} / \mathrm{m}$ 以上のピール強度を 得られていることが, 一つの基準となっている。微量エッチ ング粗化を用いた場合, $100 \mathrm{~nm}$ 以下の $50 \mathrm{~nm}$ のエッチング であっても, $0.6 \mathrm{kN} / \mathrm{m}$ 以上のピール強度を有しており, 従来 のエッチング粗化と比較して, エッチング量が約 $1 / 20$ 程度 にも関わらず同等程度の密着性が得られた。

\section{2 電解銅めっき品とソルダーレジストの密着性}

図 3 にソルダーレジストドットパターンの残存率を示す。 微量エッチング粗化と一般粗化液のソルダーレジストドッ トパターンは共に $95 \%$ 以上の残存率 $(\phi 50$ のドット 1076 個 中)となっており，ほぼ同程度の密着性を有していると判断 出来る。また, 酸洗浄(希硫酸)に打いても約 $90 \%$ と高い残 存率を得ているが, 無電解ニッケルめっき後の残存率は $40 \%$ 以下となり, 無電解ニッケルめっきの工程で多数のドッ トパターン剥離が発生している。これに対し, 微量エッチン グ粗化処理は無電解ニッケルめっき後も同等の残存率を示し ており，ニッケルめっき工程におけるソフトエッチングに, 銅表面とソルダーレジストの界面が侵されていないことが分 かる。

\section{3 無電解銅めっき品に対するドライフィルムレジス 卜の密着性}

表 1 に表面処理条件別のドライフィルムレジスト形成後の 残存最小幅及び電解めっき後のドライフィルム残存最小幅の 值を示す。

酸洗浄(希硫酸)の久行った場合, ドライフィルムレジスト の現像後の残存最小幅は $5 \mu \mathrm{m}$ であり, 電解銅めっき形成後 では $6 \mu \mathrm{m}$ が残存最小幅となった。一方，微量エッチング粗 
Table 1 The width of the remaining dry film before and after electrolytic copper plating

\begin{tabular}{c|c|c|c|c|c|c}
\hline \multicolumn{2}{c|}{} & \multicolumn{5}{c}{ The width of the dry film which remains $(\mu \mathrm{m})$} \\
\multicolumn{2}{c|}{} & 3 & 4 & 5 & 6 & 7 \\
\hline \multirow{2}{*}{$\begin{array}{c}\text { Before the electrolytic } \\
\text { copper plating }\end{array}$} & Acid cleaning & NG & NG & Good & Good & Good \\
\cline { 2 - 7 }$y$ & Etching $(100 \mathrm{~nm})$ & NG & Good & Good & Good & Good \\
\hline $\begin{array}{c}\text { After the electrolytic } \\
\text { copper plating }\end{array}$ & Acid cleaning & NG & NG & NG & Good & Good \\
\cline { 2 - 8 } & Etching $(100 \mathrm{~nm})$ & NG & Good & Good & Good & Good \\
\hline
\end{tabular}
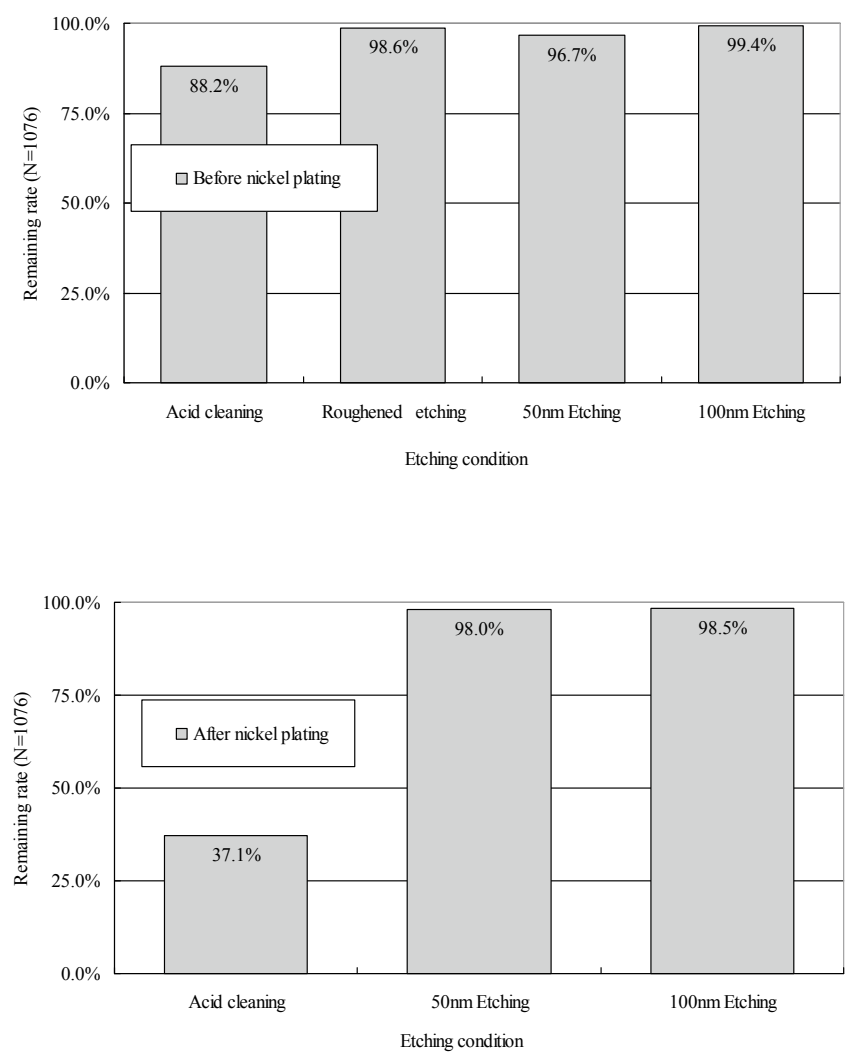

Fig. 3 Remaining rate of the SR dot patterns in different etching conditions

化液を用いて前処理を行った場合は, 最も良好な条件 $(100 \mathrm{~nm}$ Etching)において現像後で $4 \mu \mathrm{m}$ 幅のドライフィルムレジス
トが残存しており，さらに電解銅めっき形成後においても剥 離することなく, 同じ $4 \mu \mathrm{m}$ 幅で残存していることが確認さ れ，密着性が向上していることが判明した。

\section{4.まとめ}

低エッチング量かつ低粗度であっても, その得られた粗化 形状が絶縁材料に対して適合すれば, 一般的な粗化液と同等 の密着性を得ることができることが分かった。

また，銅厚の薄い無電解銅めっきへのドライフィルム前処 理として, 従来は酸洗浄で対応せざるを得なかったが, 本微 量エッチング粗化液にてその表面を加工することで, ドライ フィルムとの密着性が向上することにより，これまで困難と されてきた平滑樹脂上の $\mathrm{L} / \mathrm{S}=10 / 10$ 以下の微細配線形成に おいても，効果が期待できる。

今後の配線回路の微細化が進むには, nm オーダーの低 エッチング量，かつ低粗度の銅－絶縁材料間に対する密着性 向上対策が望まれる。本稿に記した「微量エッチング粗化技 術」は, これらの要求に対して解決手段として期待でき, 今 後のプリント配線板や電子機器関連の発展に寄与するものと 考える。

(Received August 31, 2012 ; Accepted October 15, 2012)

\section{文 献}

1) $\mathrm{NPO}$ サーキットネットワーク編著; プリント板と実装技術, p.152（日刊工業新聞社, 2005) 